\title{
DO SMALL ORGANIZATIONS HAVE AN EFFORT TO SURVIVE? SURVEY FROM SMALL CZECH ORGANIZATIONS
}

\author{
Marie Mikušováa \\ ${ }^{a}$ Ph. D, Technical University of Ostrava, Faculty of Economics, Department of Management, Ostrava, Czech Republic,
} marie.mikusova@vsb.cz.

\section{ARTICLE INFO}

Article data:

- Received: 18 June 2012

- Accepted: 20 August 2013

JEL classification: M 10, M 20, L 26

Keywords:

- Crises

- Small organization

- Prevention

- Preparation

- Survey

\section{ABSTRACT}

This paper presents some results of research carried out in 2011. The research was focused on the relationship of small organizations to crisis prevention. The purpose is to find out the attitude of small organizations to crises from strategic point of view in order to ensure not only their survival but also their competiveness. The goal is to identify what strategies, if any, small organizations use for crises prevention.

The factor analysis identified two crisis prevention strategies. One strategy is focused on creating and updating a crisis plan and crisis team. The other is based on appropriate behaviour to employees and surroundings so that the organization builds up their loyalty. Preparation for crises is mostly complicated by the financing gap which could be expected in small organizations and managers also declared they were too busy to deal with crisis prevention. Based on the statistically processed data obtained from empirical research the author came to the conclusion that, although many small organizations know their weaknesses and external threats and try to take precautionary measures, the preparation for a potential crisis has still not become a normal part of managerial work and it is not appreciated as a feature of competitiveness. Statistical tools of correlation analysis and factor analysis were used in the research.

Reference to this paper should be made as follows: Mikušová, M. 2013. Do small organizations have an effort to survive? Survey from small Czech organizations, Ekonomska istraživanja - Economic Research 26(4): 59-76 


\section{INTRODUCTION AND REFERENCES TO RELEVANT PUBLICATIONS}

The nature and occurrence of crisis events show a dynamic and varied character of crises and raise a question whether organizations are able to prevent these difficult situations. The changes in approaches of organizations to crises and crisis management were forced by the development of both external and internal environment. Among them, the involvement of top managers in crisis management, emphasis laid on precrisis phase, i.e. prevention, integration of the crisis management in corporate culture and, above all, realization that a properly working crisis management can be recognized as a source of competitive advantages can be considered as the most important. The crisis awareness improved in the recent years, just like the knowledge of conditions generated by the surroundings, market and economy and of sociotechnical systems (organizations) which are vulnerable due to failures of prediction and inspection. It cannot be safely asserted the vulnerability results from casual environmental forces or failure of technology itself (Perrow, 1999) or exclusively from human error (Reason, 1990) although it results from the two factors very often. The theories now rather need to focus on engrained organizational conditions and patterns which should predict crisis events.

This is to say the scientists and practitioners now attempt to specify organization's functionality in order to provide overall support to the crisis management and safe performance or operations prone to risk. However, understanding how an organization's vulnerability arises does not mean the future disasters can be automatically prevented. The ability of management to predict and prevent crises appears as an important condition for an organization's operation.

The researches as well as practical development of crisis management system face a number of barriers and restraints which have to be coped with by the scientists and practitioners. Studies indicate that only an insufficient percentage of organizations - typically about $50 \%$ - have a crisis plan in place and even less of them do update and test it (Jaques, 2007). An unexpected problem can be formed not by a lack, but on the contrary, an excess of information due to technologies and quickly developing databases (Sapriel, 2003). Sometimes the management is unable to identify warning signals (Regester, Larkin, 2002). There are also cases where the managers try to disguise or distort facts (Mikušová, 2010, Dočkalíková, Kashi, 2013). Disputes between departments can also cause problems which can lead to formation of intentional barriers (Horváthová, Durdová, 2011). A big role in the preparation for crises is played also by financial costs (Zenzerović, 2009). Mikušová (2012) focuses on the post-crisis period arguing that potential legal costs tend to determine the way organizations react to crisis. However, she does not deny that the market costs are the highest cost item. Coombs (2007) highlights the fact not every crisis is triggered by a "problem". An organization should use its criteria to determine when a "problem" can develop into a crisis. Early assumption of responsibility for crisis management is one of its risk factors. The crisis management is a separate discipline with strategic extent and importance far exceeding "mere" early warning in prevention (Kashi, Friedrich, 2013). Nevertheless, it is also clear both disciplines include activities aimed to help identify the problems in time and control them efficiently in order to reduce the chance the "problem" will become a crisis.

Not only the current global economic situation but the ever changing business environment with more and more fast and hard impacts particularly on small organizations presses increasingly high demands to be satisfied by them to survive (Miocevic, Crnjak-Karanovic, 2010). The vulnerable position of small organizations and their endeavour to understand the threat from potential crises were an impulse for a research project one of the outputs of which is this paper. 


\section{RESEARCH OF SMALL ORGANIZATION'S READINESS FOR CRISES}

There is not a much attention devoted to research's area of small and medium size organization's readiness for crises; it can be considered as an opportunity. E.g. the study of Herbane (2010) points out relative absence of researching crises management in small organizations. He analyzes, through case studies, the impact of crises in four small British companies. In his study he focused on understanding the risk, acquiring experiences from crises and an existence of supporting systems. He came to a conclusion that from the view of small companies it is necessary to make an effort in both: in research, public awareness and support.

Very interesting is the research study of Yiannaki (2012), which was aimed at medium-size entrepreneurial subjects in Romania and Cyprus. She considers as the condition of their long-term survival, among others, the level of fulfilling social responsibility obligation. From her research's outputs we can mention: manager's refusal to take risk and not understanding that there is a connection between crises management and strategy. Also Spillan and Hough (2003) are focusing on the importance of crises planning for small organizations. Respondents of their research were from Pennsylvania's region. They especially researched the fact that experiencing crises can influence the size of worries about potential future crises, if it instigates interest in creating crises plans and crises teams. The results of their study indicate that small and medium-size organization devote very little attention to preparation for crises even in a situation that they have experienced crises already.

Omercevic's (2012) research concentrated on diagnosing dominant types of crises management in small organization in Bosnia and Herzegovina. He studied, among others, the differences between classic management and management confronting crises. Unfortunately, it was found, that dominant types are reactive and passive crises management, even in companies that have implemented system of timely warning.

When comparing presented research's results with results of Hilliard et all. (2011) research we can find many similar outputs. Half of their respondents were small and medium-size organizations with less than fifty employees. Their research's result is the identification of element's categories that influence bankruptcy and crises preparation. Mentioned elements influence the acceptance of decision to prepare for crises, recognition of specific risk or threat's existence, and strong belief that this decision is correct. Other elements include regional place of business, customer's requirements to implement crises management, duration of crises event, awareness about activities and knowledge in the area of crises management in other organizations, own experience, and fear of financial consequences. Among elements, which justify organization's prevention absence, are most often mentioned: lack of time or specialists ( $93 \%$ of respondents), preparation is not required by top management or customers (68\%), they do not see a reason to prepare (62\%), there is not enough finance in the budget (56\%), there is not enough knowledge about crises preparation (33\%), apathy/readiness for crises is not a priority (33\%), relying on someone else who will take care of preparation for crises $(28 \%)$. Other reasons for not preparing for crises include not knowing that they should prepare for crises, strong belief that insurance will cover it sufficiently, prevention will disconcert all involved and the fear of being responsible.

Based on foreign sources, many small organizations think that: "there are no crisis in our area of business" or "our company is well managed and we will be able to deal with crises even without a plan" (Caponigro, 2000). They suppose that crises happen only to others or they are somehow protected from crises (Mitroff, 1989). Other small organizations believe that they do not have to prepare for crises because they are insured. Other argument, which is mostly mentioned 
by small organization, is that they are missing finance for crises preparation (Barton, 2007). And last, but not least some managers claim that they do not have enough time to take care of crises planning in advance. They indicate that today's problems are so complicated and time demanding that there is not any time left to plan for future uncertainty (Caponigro, 2000).

Although these objections are understandable, absence of crises planning can be harmful for running a successful small organization. Long-term business strategy and alliance must be very often sacrificed to naturalness of crises management. Managers must consider investment into crises' preparation and possible costs which can potential crises bring.

Small organization still put a relatively small emphasis on crises planning. The only impulse for concern seems to be real crises occurrence. Organizations which have not gone through crises yet are dealing with prevention very rarely. This unconcern with the need for crises planning and due to high probability that small organizations are unprepared for crises and will probably go through very difficult situations and possibly even bankruptcy is astounding.

\section{RESEARCH AND METHODS}

The objective of the research was to identify how small organizations prepare for crises.

Two hypotheses were formulated, which should be confirmed/rejected by the research. First hypothesis is: more than $50 \%$ of organizations which have experienced some crises will prepare for next crises. Second hypothesis is: minimally one third (33\%) of small organizations create conditions for preparation to manage crises.

To achieve the objective an empirical research on representative sample of entrepreneurial entities had to be conducted and data had to be statistically processed and interpreted. The research was carried out in autumn 2011. Data was acquired using quantitative and qualitative research Questions in the questionnaire were focused on objective and subjective data. The form of nominal scales (Lickert scale) was verbal. The questionnaire contained also a limited number of open questions.

The respondents were owners or executives of entrepreneurial entities with up to ten employees and yearly turnover up to ten million CZK (400 $000 €$ ) operating throughout the Czech Republic. The respondent samples were chosen by simple random selection. About five thousand respondents were addressed and 300 valid responses were received. The respondents were addressed and the questionnaires were filled in on-line. The acquired data was statistically evaluated. Nominal and ordinal measurements were taken using correlation coefficient. Dependences among the selected data were analyzed using internal and cross correlation. General conclusions regarding the preparedness of small enterprises for crises were drawn through induction of the statistically processed data.

Having found out if the organizations faced problems endangering their existence and if the problems made them take any preventive actions the author analyzed the reasons due to which the prevention efforts attempted by the organizations were complicated. The author wanted also to get the respondents' view of their knowledge of crisis management using questions intended to obtain the respondents' selfassessment. A self-confident statement of a manager claiming he has clear view and deep knowledge of crises and coping with crises can prove to be false in practice.

Mutual dependences between the selected relations are analyzed using Pearson correlation coefficient which represents initial correlation coefficient for the measurement of linear dependence between two numeric characters $X$ and $Y$ which form ordered pairs $(x[i], y[i])$. The 
application of Pearson coefficient requires normal distribution of the two characters. The formula for Pearson correlation coefficient is as follows:

$$
r=\frac{s_{X Y}}{s_{X} \cdot s_{Y}}
$$

where $s_{X Y}$ is covariance of $X$ and $Y$ characters calculated using the formula below

$$
s_{X Y}=\frac{\sum_{i=1}^{n}\left(x_{i}-\bar{x}\right)\left(y_{i}-\bar{y}\right)}{n}
$$

and $s_{X}, s_{y}$ are standard deviations of $X$ and $Y$ characters.

The correlation coefficient value ranges from -1 to +1 . Values close to 0 express independence of the two characters; positive values indicate direct (increasing) dependence and negative values show indirect (decreasing) dependence.

The correlations were evaluated also using Spearman rank correlation coefficient $r_{s}$. This coefficient is used primarily for the measurement of dependence of ordinal characters or characters showing significant deviation from normal distribution. The correlation in the contingency tables is calculated using modified Kendall tau-b correlation coefficient $\left(\tau_{b}\right)$ excluding the same values in the rank so that the results are not distorted.

Presented sets do not include remote measurements so all the three correlation coefficients have similar values. The tests of $X$ and $Y$ characters for dependency usually also lead to the same conclusions.

\section{EVALUATION OF ACQUIRED DATA AND DISCUSSION}

Three hundred valid answers were obtained. The results show the respondents were dominated by representatives of organization with less than 5 employees (64\%), with yearly turnover less than $200000 €(66 \%)$, active in the service sector (86\%), with more than 10 years' presence in the market (63\%) and with owners holding senior executive position ( $86 \%$ ).

\section{A. Has the Experienced Crisis Motivated to Prevention of Next Crisis?}

Clear majority of the respondents admitted former serious threat. Only $9 \%$ of respondents were sure they had not faced a threat endangering the existence of their organization. However, one can ask what lesson did the organizations draw, if any (Figure 1). 


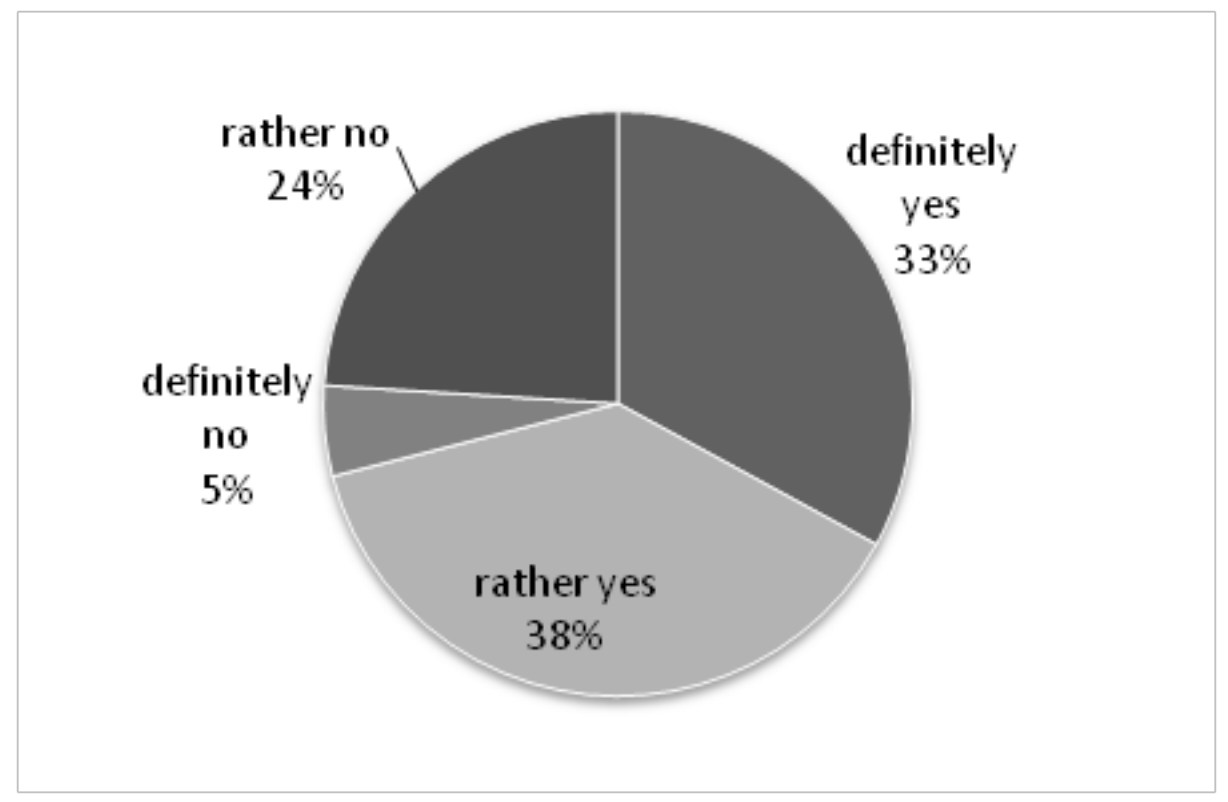

\section{FIGURE 1. HAS “THE CRISIS SITUATION” YOU WENT THROUGH MADE YOU READY TO COPE WITH POTENTIAL FUTURE CRISES?}

\section{Source: Author}

Almost three quarters (71\%) of the organizations who went through a crisis situation were induced by the problems experienced to make ready to cope with potential future serious threats by working out, for example, alternatives of decisions, reserve plans, emergency plans, etc.

A significant positive dependence between the crisis experienced and subsequent prevention was confirmed by the calculated correlation coefficients ( $N=300$ respondents):

Q1: Have you gone through a crisis? Q2: Do you prepare for crises?

Pearson correlation coefficient $r=0.202$

Spearman rank coefficient $r_{s}=0.245$

Kendall tau-b coefficient $r_{b}=0.213$

The statistical tests showed a significant positive correlation at the levels of $\alpha=0.05$ and $\alpha=0.01$ in all the three cases.

Testing of first hypothesis (more than $50 \%$ of organizations which experienced some crisis will prepare for other crises) derived from following values:

Selection sample $\mathrm{n}$ (number of organizations which experienced crisis) $=214$

$m$ (number of organizations which consequently started to prepare for crisis) $=213$

$\mathrm{p}_{0}($ relative frequency $)=50 \%$, i.e. 0.5

level of significance: $\alpha=0,05$

construction of critical range $W_{\alpha}$ equals $W_{0,05}=\left\{U \geq u_{0,95}\right\}=\{U \geq 1,645\}$ 
$\mathrm{H}_{0}: \mathrm{p}=\mathrm{p}_{0}$ assumption does not differ from reality

$\mathrm{H}_{1}: \mathrm{p} \neq \mathrm{p}_{0}$ assumption differs from reality

Test criteria for test of relative frequency: $U=\frac{\frac{m}{n}-p_{0}}{\sqrt{\frac{p_{0}\left(1-p_{0}\right)}{n}}}$

$U=14,\{U \geq 1,645\}$

After assigning numbers to the formula (3) it was found that value $U=14$. Relation $\{U \geq 1,645\}$ applies.

Conclusion: It can be stated that more than half of organizations which have experienced crises will consequently prepare for other crises.

\section{B. Is it Unnecessary to Prepare for Crises?}

Most of the respondents realize the increasing threat as $88 \%$ of them acknowledge the importance of preparation for crises. But there are still those who consider the preventive actions as unnecessary (Figure 2). Why is it so?

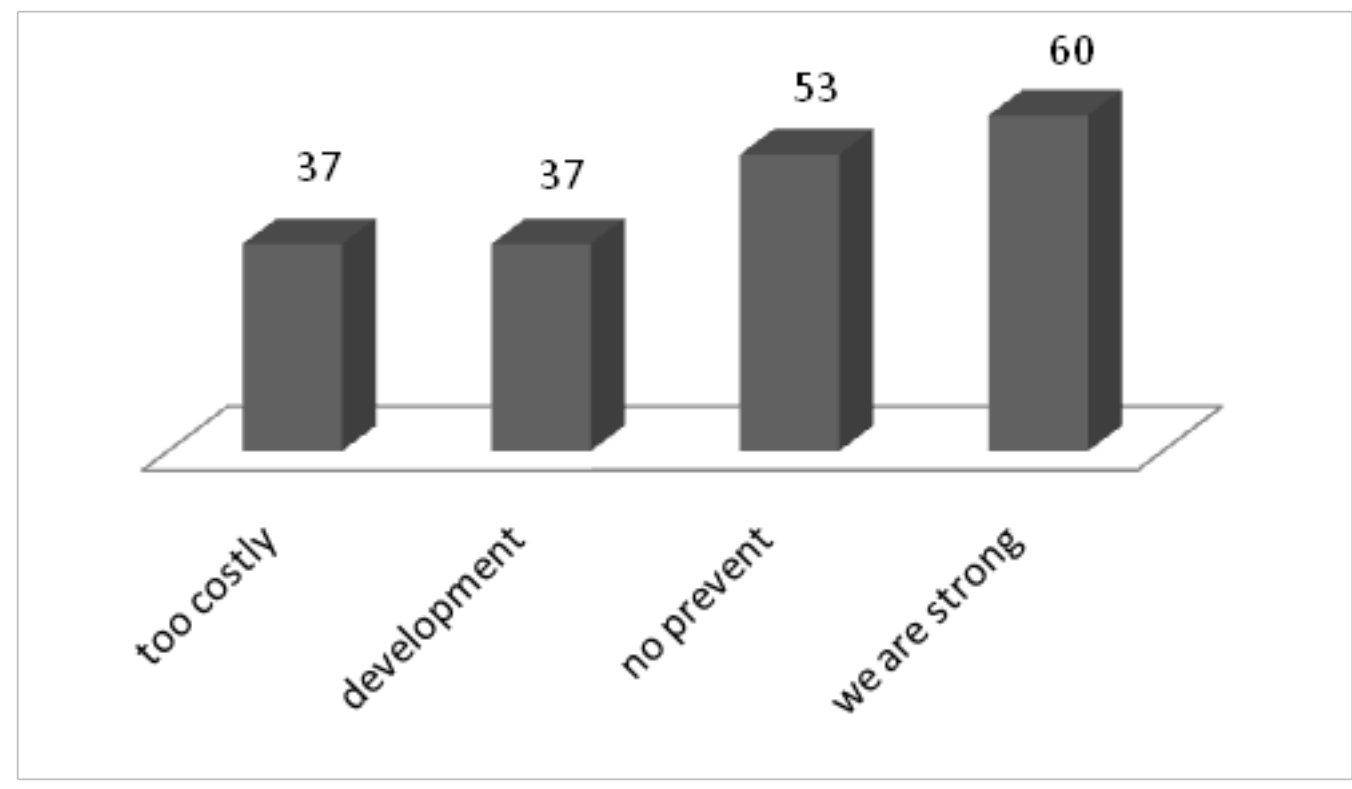

FIGURE 2. FOR WHAT REASON YOU DO NOT CONSIDER THE PREPARATION FOR THE CRISIS IMPORTANT? (\%) 
Those who did not consider the preparation for crises as important ( $12 \%$ of respondents) mostly defended themselves by claiming they enjoyed a strong position (thanks to strategic partner, excellent product, abundance of finance, etc.) so they were not afraid of a crisis. This was claimed by as many as $60 \%$ of them.

An important role in the creation of their opinion is played by the high costs associated with the prevention ( $37 \%$ ) in combination with alleged uselessness of prevention because it cannot avert the crisis ( $53 \%$ ) and opinion that the crisis will finally develop otherwise than anticipated by the preventive actions (reserve plans) (37\%).

Overall, it can be stated although the respondents recognize the potential threat they have built-in defensive mechanisms related particularly to unforeseeability (crises are unforeseeable so one cannot prepare for them), costs (crisis management is too costly) and conviction of their omnipotence (we are powerful, we need not be afraid of crises). Their attitudes incline to fatalism and tend to prove fatal in future.

\section{What does Complicate the Preparation for Coping with Crises?}

Proactive organizations, i.e. those which actively prepare for coping with crises, are confronted with numerous complications. These typically take the form of lack of appropriate experts among employees (39\%) combined with lack of finance to train them or invite external experts (47\%). 47 $\%$ of respondents associate the complications with the fact they are too busy to spend any time for crisis prevention. The results were not surprising due to generally limited financial and human resources available to small organizations. The lack of time for crisis prevention is regarded by the author as disputable reason with respect to the fact most of the responding managers were the organization owners. At such circumstances - especially in small organizations - the managers/ owners usually tend to get control over all issues refusing to delegate powers and responsibilities (or avoiding doing so for other reasons). This fact may be one of the causes of crisis.

The answers to supplementary open question regarding this topic can be divided into several areas. One area, occurring very frequently, is the legislation and political environment where the respondents typically mentioned complications such as unenforceability of law, frequent amendments of legislation, poor support of small businesses from the government, tax burden, approach of government administration, bureaucracy, approach of banks to applicants for loan, huge administrative burden and unfair competition. The answers were generally based on the respondents' experience. Another area is formed by the business environment where the respondents referred to strong competition from Asian goods and hypermarkets, dependence on other supply chain members and bad payers. An interesting but rather rare area is self-criticism of respondents. Some of them admitted their reluctance to solicit orders when their influx had died down in crisis time and lack of determination and endeavor to tackle the problems. 


\section{Conditions for Coping with Crises}

The respondents were asked to indicate to what extent has their organization created the below listed conditions for coping with crises (Figure 3).

The respondents could select from the following questions proposed:

- We treat our employees in such a way that in case of a crisis breaking out we can rely on their loyalty and helpfulness.

- We treat our residents, business contacts, state institutions etc. in such a way that we have built up their confidence.

- We have worked out crisis plans - a reserve solution, alternatives for the determined situations.

- We update our crisis plans - alternatives of solution.

- We have made up a crisis team (list of people with the required expertise to deal with the determined crisis situation).

- We know about our weaknesses - an old product, lack of finance and the like.

- We know about external threats - competition, legislation, distribution and the like.

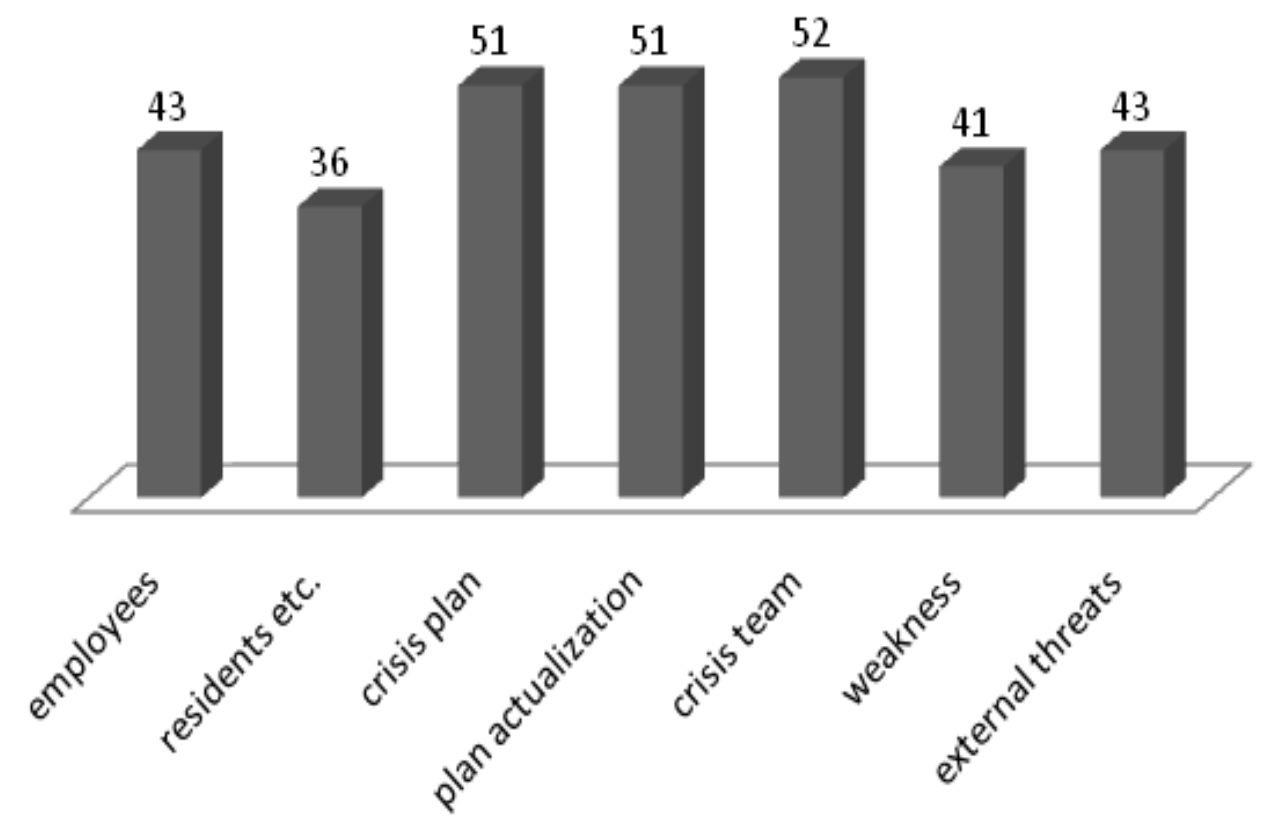

FIGURE 3. TO WHAT EXTENT HAS YOUR ORGANIZATION CREATED THE FOLLOWING CONDITIONS FOR COPING WITH CRISES? (\%)

Source: Author 
The last section of the questionnaire indicates the respondents' positive self-assessment. The managers have high opinion of their organizations, both in terms of employees and relations to surroundings. They are convinced their behavior makes them trustworthy in the eyes of their employees ( $43 \%$ ) and surroundings ( $36 \%$ ). The knowledge of potential threats is also high. The respondents know their weaknesses. A similar number of them answered they knew the external threats. The closest attention is paid to developing crisis plan (51\%) and making up crisis teams (52\%). However, the mobilization potential of crisis plans is given quite a low priority for a mere half of them is updated so that they reflect the actual circumstances.

When testing second hypothesis (minimally one third (33\%) of small organizations create conditions for preparation to manage crises) derived from following values:

Selection sample $\mathrm{n}=301$ i.e. 1849 answers

$\mathrm{m}$ (affirmative answer to creating conditions) $=875$

$\mathrm{p}_{0}$ (relative frequency) $=33 \%$, i.e. 0.33 .

Level of significance and hypotheses formulation are the same as in previous assumption. After substituting the formula (3) the value $U=14$ was calculated. Relation $\{U \geq 1,645\}$ applies. Conclusion: It can be stated that minimum one third of small organizations creates conditions for preparation and management of crises.

\section{E. Internal and Cross Correlations}

The selected relations were subjected to additional analysis using internal and cross correlations between answers of both attitude batteries in the research questionnaire.

\section{Internal Correlations}

The correlations between the different battery items were analyzed. The respondents did not select answers closest to their understanding of the issue but expressed the degree of their agreement/disagreement with the proposed answers on ascending five-point ordinal Lickert scale where $1=$ "definitely no" to $5=$ "definitely yes". Ordinal Kendall tau-b correlation coefficient $\left(\tau_{b}\right)$ was used to express the dependence degree in all cases. The dependence was tested at significance levels of $\alpha=0.05$ (significant dependence marked with an asterisk after $\tau_{b}$ value in the table) and $\alpha=0.01$ (very significant dependence marked with two asterisks).

Because the correlation coefficient is paired and symmetrical the correlation analysis result is shown in the form of Fuller's triangle which is actually a lower diagonal matrix of correlation coefficients. The significant dependences are shown in bold (Table 1). 
TABLE 1. INTERNAL CORRELATION „TO WHAT EXTENT HAS YOUR ORGANIZATION CREATED THE FOLLOWING CONDITIONS FOR COPING WITH CRISES?" ( $\mathrm{N}=300$ RESPONDENTS)

\begin{tabular}{|c|c|c|c|c|c|c|}
\hline $\begin{array}{l}\text { Correlation } \\
\text { Fullers' triangle }\end{array}$ & $\begin{array}{l}\text { We treat } \\
\text { our employ- } \\
\text { ees }\end{array}$ & $\begin{array}{l}\text { We treat our } \\
\text { residents etc. }\end{array}$ & $\begin{array}{l}\text { We update } \\
\text { our crisis } \\
\text { plans }\end{array}$ & $\begin{array}{l}\text { We have } \\
\text { made up a } \\
\text { crisis team }\end{array}$ & $\begin{array}{l}\text { We have } \\
\text { worked } \\
\text { out crisis } \\
\text { plans }\end{array}$ & $\begin{array}{l}\text { We know } \\
\text { about our } \\
\text { weaknesses }\end{array}$ \\
\hline $\begin{array}{l}\text { We treat our } \\
\text { residents etc. }\end{array}$ & $0,349 * *$ & & & & & \\
\hline $\begin{array}{l}\text { We update } \\
\text { our crisis plans }\end{array}$ & $-0,013$ & $-0,010$ & & & & \\
\hline $\begin{array}{l}\text { We have made } \\
\text { up a crisis team }\end{array}$ & $-0,063$ & 0,004 & $0,108^{*}$ & & & \\
\hline $\begin{array}{l}\text { We have worked } \\
\text { out crisis plans }\end{array}$ & $0,087^{*}$ & 0,016 & $0,501^{* *}$ & $0,197^{* *}$ & & \\
\hline $\begin{array}{l}\text { We know about } \\
\text { our weaknesses }\end{array}$ & $0,204^{* *}$ & $0,254^{* *}$ & 0,006 & 0,015 & $-0,010$ & \\
\hline $\begin{array}{l}\text { We know about } \\
\text { external threats }\end{array}$ & $0,098^{*}$ & $0,231^{* *}$ & $-0,008$ & $-0,022$ & $-0,060$ & $0,234^{* *}$ \\
\hline
\end{tabular}

Source: Author's calculation

The table includes two groups of interlinked items (with significant positive correlations):

- We have made up a crisis team; We have worked out crisis plans; We update our crisis plans.

- We take care of our employees; We take care of our residents; We know about our weaknesses; We know about external threats.

The two opinion groups above can represent two different strategies applied by organizations to cope with crises and prevent crises $a$ ) - We rely on crisis team and crisis plans; $b$ ) - We rely on loyalty of employees and our residents etc. The correctness of this approach can be proved using factor analysis applied to this battery (Table 2). 
TABLE 2. FACTOR ANALYSIS „TO WHAT EXTENT HAS YOUR ORGANIZATION CREATED THE FOLLOWING CONDITIONS FOR COPING WITH CRISES?" ( $N=300$ RESPONDENTS) - RESULTING DECOMPOSITION OF THE FACTORS

\begin{tabular}{|c|c|c|c|}
\hline \multicolumn{4}{|l|}{ Rotated Component Matrix ${ }^{a}$} \\
\hline & \multicolumn{3}{|c|}{ Component } \\
\hline & 1 & 2 & \\
\hline we treat our residents, business contacts, etc. & \multicolumn{3}{|l|}{,754 } \\
\hline we treat our employees & \multicolumn{3}{|l|}{691} \\
\hline we know about our weaknesses - an old product, lack of finance and the like & \multicolumn{3}{|l|}{, 642} \\
\hline we know about external threats - competition, legislation and the like & \multicolumn{3}{|l|}{, 539} \\
\hline \multicolumn{4}{|l|}{ we have worked out crisis plans - a reserve solution, alternatives } \\
\hline we update our crisis plans - alternatives of solution. & & & ,800 \\
\hline we have made up a crisis team. &,- 108 & & ,497 \\
\hline \multicolumn{4}{|c|}{$\begin{array}{l}\text { Extraction Method: Principal Component Analysis. Rotation Method: Equamax with Kaiser Normalization. a. Rota- } \\
\text { tion converged in } 3 \text { iterations. }\end{array}$} \\
\hline
\end{tabular}

Source: Author's calculation

The analysis of main components using Kaiser criterion identified two significant factors, as originally expected. The factors cover (explain) $49.5 \%$ of entire battery variability. Using the solution based on equamax rotation just the four components identified as group $b$ (loyalty) in the correlation matrix were included into the first factor. The "We have worked out crisis plans" and "We update our crisis plans" components from group a (crisis plans) were included into the second factor. The conclusion regarding two strategies for preparation for crises and facing crises drawn from the correlation analysis was thus confirmed.

In the "What prevents you (causes complications) from the preparation for coping with a crisis?" battery all $\mathrm{N}=300$ respondents provided their answers again. A very strong dependence ( $\alpha$ $<0.01$ ) between the "We do not have necessary experts among our employees" and "We do not have finance to train (educate) our employees/experts or to invite external experts" opinions was identified. Due to a small number of opinions in this battery and a single significant correlation any opinion segmentation is useless in this case.

\section{Cross Correlations}

Cross correlations are used to analyze the dependences between items of two batteries. In the concerned case the "To what extent has your organization created the following conditions for coping with crises?" and "What prevents you (causes complications) from the preparation for coping with a crisis?" batteries can be made use of. In addition, they involve the same Lickert scale for evaluation of attitudes (Table 3).

A graphic view of the cross correlations is provided by two-dimensional table (matrix) of correlation coefficients where the rows include items of one battery and columns include items of 
the other battery. To express the dependence degree ordinal Kendall tau-b correlation coefficient $\left(\tau_{b}\right)$ was used again and the dependence was tested at the significance levels of $\alpha=0.05$ and $\alpha=$ 0.01 . The significant dependences are shown in bold like in the previous tables.

TABLE 3. CROSS-CORRELATION BETWEEN „TO WHAT EXTENT HAS YOUR ORGANIZATION CREATED THE FOLLOWING CONDITIONS FOR COPING WITH CRISES?"“ AND „WHAT PREVENTS YOU (CAUSES COMPLICATIONS) FROM THE PREPARATION FOR COPING WITH A CRISIS?" ( $\mathrm{N}=300$ RESPONDENTS)

\begin{tabular}{|c|c|c|c|}
\hline Cross-correlation & $\begin{array}{l}\text { We do not have finance } \\
\text { to train our employees/ } \\
\text { experts or to invite } \\
\text { external experts }\end{array}$ & $\begin{array}{l}\text { We do not have neces- } \\
\text { sary experts among our } \\
\text { employees }\end{array}$ & $\begin{array}{l}\text { We are too busy to } \\
\text { deal with crisis pre- } \\
\text { vention }\end{array}$ \\
\hline We have made up a crisis team & $0,138^{* *}$ & 0,021 & $0,099^{*}$ \\
\hline $\begin{array}{l}\text { We have worked out crisis } \\
\text { plans }\end{array}$ & $0,085^{*}$ & $0,089^{*}$ & $0,105^{*}$ \\
\hline We update our crisis plans & 0,056 & 0,073 & 0,018 \\
\hline We treat our employees & 0,040 & $0,105^{*}$ & 0,077 \\
\hline We treat our residents etc. & 0,084 & 0,045 & $0,149^{* *}$ \\
\hline $\begin{array}{l}\text { We know about our weak- } \\
\text { nesses }\end{array}$ & 0,063 & 0,055 & $0,088^{*}$ \\
\hline $\begin{array}{l}\text { We know about external } \\
\text { threats }\end{array}$ & $0,094^{*}$ & $0,104^{*}$ & $0,153^{* *}$ \\
\hline
\end{tabular}

Source: Author's calculation

The table rows are arranged so that the attitudes corresponding to strategies (a) and (b) from Table 1 remain together. It is clear the "We update our crisis plans" opinion does not significantly correlate with any attitude from the other group (complications). All significant correlations are positive (highlighted in the table).

Strategy (a) - crisis plans (We have made up a crisis team; We have worked out crisis plans; We update our crisis plans) - correlates most closely with the "We do not have finance to train (educate) our employees/experts or to invite external experts" opinion and, to some extent, also with the "We are too busy to deal with crisis prevention" opinion. Strategy (b) - loyalty (We treat our employees in such a way that in case of a crisis breaking out we can rely on their loyalty and helpfulness; We treat our residents, business contacts, state institutions etc. in such a way that we have built up their confidence; We know about our weaknesses; We know about external threats) - correlates most closely with the "We are too busy to deal with crisis prevention" attitude.

Based on this it can be argued that also in the sphere of crisis prevention and preparation for crises the most important role is played by lack-of-time and lack-of-money factors.

If reliability analysis is used to join the two batteries from the previous table Cronbach value of $\alpha=$ 0.535 can be obtained and it would not be increased any more by deleting any item. The opinions in the two batteries are thus surprisingly relatively homogeneous (consistent). Both batteries can therefore be looked upon as a single opinion group and the factor analysis can be attempted again (Table 4). 


\section{TABLE 4. FACTOR ANALYSIS FOR BOTH GROUPS ( $N=300$ RESPONDENTS) - RESULTING DECOMPOSITION OF THE FACTORS ROTATED COMPONENT MATRIX ${ }^{A}$}

\section{Component}

\begin{tabular}{llll}
\hline \hline 1 & 2 & 3 & 4
\end{tabular}

„To what extent has your organization created the following conditions for coping with crises?" We treat our employees in such a way that in case of a crisis breaking , 754 out we can rely on their loyalty and helpfulness.

„To what extent...?" We treat our residents, business contacts, state institutions etc. in such a way that we have built up their confidence.

"To what extent...?" We know about our weaknesses - an old product, lack of finance and the like.

„To what extent...?" We have worked out crisis plans - a reserve solution, alternatives for the determined situations.

„What prevents you (causes complications) from the preparation for coping with a crisis?" We do not have finance to train (educate) our employees/experts or to invite external experts.

Extraction Method: Principal Component Analysis. Rotation Method: Equamax with Kaiser Normalization. a. Rotation converged in 6 iterations.

Source: Author's calculation 
The use of Kaiser criterion (eigenvalue $>1$ ) leads to identification of 4 factors. About $59 \%$ of variability of the two batteries is distributed among them this time. The solution based on equamax rotation then results in the inclusion of the following components into these factors:

- We take care of our employees; We take care of our residents etc; We know about our weaknesses.

- We have worked out crisis plans; We update our crisis plans.

- We do not have finance to train (educate) our employees/experts or to invite external experts; We do not have necessary experts among our employees.

- We are too busy to deal with crisis prevention; We have made up a crisis team; We know about external threats.

The first two factors more or less correspond to those from the original factor analysis (loyalty and crisis plans) and include only items from this battery (To what extent has your organization created the following conditions for coping with crises?). The third factor similarly covers two components of the other battery (What prevents you (causes complications) from the preparation for coping with a crisis?) pointing out lack of experts and money. The last factor combines items from both batteries pointing out knowledge of external threats, preparedness in the form of crisis team as well as lack of time to deal with this issue.

\section{CONCLUSIONS: WHAT IS THE PROFILE OF A SMALL ORGANIZATION WHICH PREPARES FOR CRISES?}

Answers from 300 respondents were obtained in the research. $74 \%$ of all respondents had faced a serious threat endangering the existence of their organization. $71 \%$ of them have started to prepare for a potential future threat. Proactive organizations (those which actively take preventive actions) can be found mostly in the service sector ( $57 \%$ ), all of them employ up to 10 people and $55 \%$ of them less than 5 people, their yearly turnover is mostly less than $200000 €(62 \%)$, their presence in the market is mostly longer than 5 years and $64 \%$ of them show market presence longer than 10 years. At most of them ( $86 \%$ ) the owner holds senior executive position.

The factor analysis identified two strategies applied by small organizations to prepare for crises and prevent crises:

- We rely on crisis team and crisis plans;

- We rely on loyalty of employees and our residents, business contacts, state institutions etc.

It can also be stated that in the sphere of crisis prevention and preparation for crises the most important role is played by lack-of-time and lackoffinance factors.

The endeavor of the addressed small organizations to take preventive actions, whatever their extent might be, is creditable. On the other hand, quality and efficiency of the actions may be low (due to unclear crisis management understanding and low availability of relevant information). The position of manufacturing organizations in crisis prevention was more favorable because they could include also actions related to scrap rate monitoring, etc.

A senior executive position held by the owner at most of the proactive organizations may reflect the care for own assets which must be ensured in another way in case of hired executives. 


\section{ACKNOWLEDGEMENTS}

I would like to thank Sanja Blazevic (executive editor) and two anonymous referees for valuable comments that helped me to improve an earlier version of the manuscript.

The paper was created in the framework of ESF project CZ.1.07/2.3.00/20.0296.

\section{REFERENCES}

Barton, L. Crisis Leadership Now: A Real-World Guide to Preparing for Threats, Disaster, Sabotage, and Scandal. New York: McGraw-Hill, 2007.

Caponigro, J. R. The Crisis Counselor. New York: McGraw-Hill, 2000.

Coombs, T. Ongoing Crisis Communication: Planning, managing and Responding. New York: Sage, 2007.

Dočkalíková, I. and K. Kashi. "Selection of Employees: Multiple Attribute Decision Making Methods in Personnel Management", In 9th European Conference on Management and Leadership, 2013, in print.

Herbane, B. "Exploring Crisis Management in UK Small - and Medium-Sized Enterprises", Journal of Contingencies \& Crisis Management, 21 (2012): 82-95.

Hilliard, T., S. Scott-Halsell and P. Radesh. "Elements that Influence the Implementation of Crisis Preparedness Measures by Meeging Planner", Journal of Contingencies \& Crisis Management, 19 (4), (2011): 198-206.

Horváthová, P. and I. Durdová. "Talent management and its use in the field of human resources management in the organization of the Czech Republic", WASET, 77 (2011): 809-823.

Jaques, T. "Issue management and crisis management: An integrated, non-linear, relation construct", Public Relation Review, 33 (2007): 147-157.

Kashi, K. and V. Friedrich. "Manager's Core Competencies: Applying the Analytic Hierarchy Process Method in Human Resources", In 9th European Conference on Management and Leadership, 2013, in print.

Mikušová, M. "Economic and Technological Views on the Crisis and Crisis Management", Business and Economics Research Book Series: International proceedings of economics Development and Research, 1 (2010): 15-19.

Mikušová, M. Crisis management. Review of interdisciplinary approaches to crisis and crisis management. Saarbrucken: LAP, 2012.

Miocevic, D. and B. Crnjak-Karanovic. "New Realities of the SME Internationalization: A Capability Perspective", Ekonomska istraživanja. 23 (3), (2010): 43-56.

Mitroff, I., T. Pauchant, M. Finney and C. Pearson. "Do (some) organizations cause their own crises? The cultural profiles of crisis-prone vs. crisis-prepared organizations", Organization \& Environment, 3 (4), (1989): 269-283.

Omercevic, S. "The most dominant forms of crisis management, occurring in small and middle companies in transition lands", TTEM. 7 (3), (2012): 1001-1012. 
Spillan, J. and M. Hough. "Crisis Planning in Small Businesses: Importance, Impetus and Indifference", European Management Journal, 21 (3), (2008): 398-407.

Perrow, C. Normal Accidents. Living with HighRisk Technologies. Princeton University Press, 1999.

Reason, J. Human Error. Cambridge University Press, 1990.

Regester, M. and J. Larking. Risk issues and crisis management. London: Kogan, 2002.

Sapriel, C. "Effective crisis management: Tools and best practice for the new millennium", Journal of Communication Management, 7 (4), (2003): 348-355.

Yiannaki, S. M. "A systemic risk management model for SMEs under financial crisis", International Journal of Organizational Analysis, 20 (4), (2012): 406-422.

Zenzerović, R. "Business' Financial Problems Prediction - Croatian Experience", Ekonomska istraživanja, 22 (4), (2009): 1-16. 


\title{
TRUDE LI SE MALE ORGANIZACIJE PREŽIVJETI? ISTRAŽIVANJE MEĐU ČEŠKIM MALIM ORGANIZACIJAMA
}

\begin{abstract}
SAŽETAK
Ovaj rad predstavlja neke rezultate istraživanja provedenog 2011. Istraživanje se koncentriralo na stavove malih organizacija prema prevenciji krize. Cilj je bio istražiti stav malih organizacija prema krizi sa strateškog gledišta kako bi se osiguralo ne samo njihovo preživljavanje već i konkurentnost. Cilj je utvrditi koje strategije, ako uopće, male organizacije koriste za prevenciju krize.

Faktorska analiza je utvrdila dvije strategije za prevenciju krize. Jedna se strategija usredotočuje na stvaranje i obnavljanje kriznog plana i kriznog stožera. Druga se zasniva na prikladnom ponašanju prema zaposlenima i okolini kako bi se potakla lojalnost organizaciji. Spremanje za krizu je uglavnom ometeno financijskim problemima koje je moguće očekivati u malim organizacijama tako da menadžeri često izjavljuju da su bili prezauzeti ako bi se bavili prevencijom krize. Na osnovu statistički obrađenih podataka dobivenih empirijskim istraživanjem, autor dolazi do zaključka da, iako mnoge male organizacije poznaju svoje slabosti i vanjske prijetnje te pokušavaju poduzeti preventivne mjere, priprema za potencijalnu krizu još uvijek nije postala normalni dio menadžerskog posla te nije prepoznata kao komponenta konkurentnosti. $U$ istraživanju su korišteni statistički alati za analizu korelacije i faktorska analiza.
\end{abstract}

Ključne riječi: krize, male organizacije, prevencija, priprema, istraživanje 